\title{
The Earlier Era of Eco-Technology: Pavilions at the Colonial Exhibition of Pasar Gambir and the 'Eastern-Western' Architectural Influences in the Netherlands Indies
}

\author{
Yulia Nurliani Lukito $^{1}$, Fildza Miranda $^{2}$ \\ ${ }^{1,2}$ Department of Architecture, Faculty of Engineering, Universitas Indonesia, Depok, Indonesia
}

\begin{abstract}
This paper examines architecture in the Netherlands Indies and analyses how some innovation in the practice of architecture is actually coming from an adaptation to local conditions. It is in the notion of sustainable architecture not as a single entity of Western descendent but as loaded with cultural, historical and local contexts that this paper gravitates. As the discussion are pavilions in Pasar Gambir of Batavia - a temporary architecture practices and ITB main hall that was designed with a strong connection to local conditions. During the Dutch colonial time in Indonesia there was already eco-technological practice in architecture with the aim to adapt to local conditions. The discussion of pavilions in Pasar Gambir showed some innovation in building forms, although temporary, that not only pushed the limit of building tradition but also created extraordinary event for colonial society. The discussion of ITB building illustrate the possibility of combining western-eastern architectural principles and surpassing the limit of architectural forms. In conclusion, the earlier of eco-technology in the Netherlands Indies has shown deeper cultural, historical and local meanings and how traditional architecture is related to the social and cultural dimensions of sustainability.
\end{abstract}

\section{Objectives}

In recent years, the issue of sustainable architecture has been widely accepted as one of important issues in architectural education and practice. Some scholars argue that sustainable architecture can be understood from different approaches such as according to sociocultural practices, each with its own history, geography, and politics (Guy S. and Moore S.A., 2007). As a matter of fact, studies on sustainable architecture have been for the most part limited to the Euro-American contexts. Although there are some examples from the nonWestern countries, those examples usually serve to demonstrate that sustainable architecture is a single global entity - one without history and differentiated only in terms of technological formations responding to geographical variations, such as climate and ecology, but entirely unaffected by socio-cultural influences.

This paper proposes to contribute to the variety of approaches of sustainable architecture by discussing tropical architecture in Indonesia, in relation to the social, cultural and historical conditions during the Dutch colonial contexts. Tropical architecture is a variant of sustainable architecture that aims to minimizing resource usage and the concern for social and cultural issues of a locality (Lauber et al., 2005). Therefore, the discussion of tropical architecture in this paper refers to the architectural practices that develop to deal with tropical climate and environmental conditions as the primary determinant of architectural forms.

This paper examines architecture during colonial Indonesia or the Netherlands Indies, because the practice of architecture during this time also showed an adaptation to local conditions. It is in the effort to examine sustainable architecture not as a single entity of Western descendent but as loaded with cultural, historical and local contexts that this paper will be settled. As the case study is temporary architecture practices during the Dutch colonial era in the Netherlands Indies because the architectural practice during that time presented some innovations and relations to tropical architecture.

Although mainly concerned with architectural adaptation for Dutch colonial society, there are some socio-cultural aspects of the architecture of the colonial exhibition that gives a base for significant influences over the discourses and practices of tropical sustainable architecture in Indonesia. Not only during this time there was a protagonist of tropical architecture, such as a Dutch architect practicing in the Indies Henri Maclaine Pont who tried to incorporate local forms and materials in their designs but also their works illustrated beyond East-West socio-cultural dichotomy.

There are two main parts in this paper, each representing a particular idea of tropical architecture especially with its own ideas of sustainability and 
relations with colonial history. In the first part, we examine colonial buildings in Batavia in relation to the notions of tropical architecture and modernization during the Dutch colonial era. In the second part, we examine how the traditional is imbued with the ecological and technological criticism of the tradition and how traditional architecture is related to the social and cultural dimensions of sustainability.

\section{Methods}

The research method adopted for this paper is mostly based on qualitative approach. Primary data is obtained from selected case studies of colonial buildings in Batavia and secondary data is collected from literature review. The analysis in this paper is conducted to both the primary and secondary information, while discussion on tropical and sustainable architecture is done through some comparison of earlier results of analysis. A conclusion is drawn based on the results of analysis and discussions on colonial buildings in the Indies.

\section{Discussion}

In the early of twentieth century, there was a development of technology and an expansion of cultural ascendancy of the middle class that introduced the Netherlands Indies to modernity. Local people had been exposed to new technology and modern lifestyles and they started to model their colonial counterparts as a way of dealing with modernity. The use of both Western and local products as well as practicing modern lifestyles were part of daily lives in the Indies. Although in reality a clear dichotomy between the colonizer and the colonized was still present, there were some events that allowed local middle class to practice Western culture. One of the important event was at colonial exhibitions held in major cities in Java, for instance Pasar Gambir of Batavia, Jaarbeurs in Bandung and Jaarmarkt in Surabaya. The buildings for those colonial exhibitions were innovative in a sense they showed a new building style that combine Western and Indies architecture.

Those temporary exhibitions attracted diverse crowd ranging from Europeans, Chinese and local middle-class and became a rare moment where both the colonizer and the colonized practiced modernity. During the flourish periods of colonial exhibitions in the Indies, roughly between 1920s-1930s, the organizer presented hybrid architecture that adopts both European and Indies architectural elements and somehow illustrated how the two contrasting cultures could live together in harmony. The colonial exhibitions offered a temporary 'negotiating moment' for both the colonized and the colonizer to mingle and enjoy each other's company by creating a utopian-neutral ground and using leisure as its façade.

This paper discusses tropical architecture as part of the earlier idea of sustainability and how by following local wisdom and responding to local climate mean saving energy and resources as well as dealing with local issues. In contrast to the stereotype understanding of sustainability as technical and mechanical system of the building, there is an emergence of an alternative line of thought that are related to sustainability in architecture. As example to those alternative ideas are Alexander Tzonis and Lianne Lefaivre in Critical Regionalism (Lefaivre, L. \& Tzonis, A. 2003) and Hawkes in the Selective Environment: An Approach to Environmentally Responsive Architecture (Hawkes et al., 2002) that rest upon specific place and culture in realizing sustainable architecture.

There are basically two tendencies in addressing sustainability in architecture. First is adopting passive cooling strategies for residential and public buildings through modern architectural principles and technology. Second is reinterpreting the classic metaphor for tropical architecture such as using big roofs as an umbrella that offers protection from the sun and rain as well as exploring further possibilities (Chang, 2010). Both tendencies are actually rooted in localities such as the use of local materials and technologies and the long search of suitable architectural forms for local climate and socio-cultural conditions.

Reyner Banham (1969) in the Architecture of the Well-Tempered Environment mentions three distinct modes of environmental domain that may be applied in architecture. He calls them the conservative, the selective and the regenerative based on his empirical observation of historical building types. Those three modes of environmental domain are then simplified in 1980 by Hawkes in order to make a clear distinction in environmental design strategy and calls them the exclusive and the selective.

A basic idea in exclusive mode for tropical climate is a tropical adaptation usually requires plans that use technological systems in order to utilize energy more efficiently. In architecture, the exclusive mode is related to the use of International Style modern buildings that is then modified with efficient air-conditioning and lighting systems to reduce energy consumption and ecological footprints. The basic idea of selective mode is using a variable mixture of natural and artificial that seeks to maximize the potential use of ambient energy.

In relation to technology for different climates, engineers and architects may group information on local conditions into climatic zones and use the information to create standards and instrument to help simulate the effectiveness of sun-shading devices in different localities at different times of a year. As a result, an architect based in Amsterdam can propose design for different localities in the tropics without having to visit the places. In this way, modern tropical architecture can be understood as a power-knowledge relationship and the ability to act from a distance.

However, knowing local conditions are still important before one can propose design. The discussion in this paper will examine the richness of the history and local that indirectly relate to the earlier conception of sustainability and eco-technology in Indonesia.

Some important colonial projects designed by Dutch architects in the Netherlands Indies seems to 
demonstrate the two tendencies mentioned above, started with Henri Maclaine Pont's design for Technische Hoogeschool in Bandung (now Institut Teknologi Bandung) in 1918 and the market project in Semarang designed by Thomas Karsten. Both projects were known as a 'synthesis' of Western and Indies architecture. The two public buildings can be interpreted through the incorporation of local architectural features, such as roof extension that worked as sun-shading, wide openings for cross-ventilation and the use of local materials.

Due to the convergence of Dutch colonial architecture with local building traditions and the adaptation to the local climate, Technische Hoogeschool in Bandung received praise from a well-known Dutch architect Hendrikus Petrus Berlage. In his review, Berlage said that Maclaine Pont already had a good proportion and composition and as well as a perfect combination between Indies architectural style and European architectural design principles.

During the 1920s and the 1930s there was a yearly Pasar Gambir fair held in Koningsplein Batavia or nowadays Lapangan Merdeka, Jakarta. The chairman of the Pasar Gambir Committee Meyroos proudly mentioned the popularity of Pasar Gambir for in the Dutch colony and how the colonial exhibition was associated with lights and leisure, two signs of modernity. Pavilions at Pasar Gambir were built every year, each time with different architectural forms but always using Indies vernacular architecture as references. The architect of Pasar Gambir J.H. Antonisse brought together local and Western architectural forms that in the end created hybrid architecture that had never happened before. Pasar Gambir was not only successfully transported the tradition of the nineteenth century world fairs in the West but also gave way to hybrid architecture that dealt with locality to a greater extend.

\subsection{The 1927 Pasar Gambir}

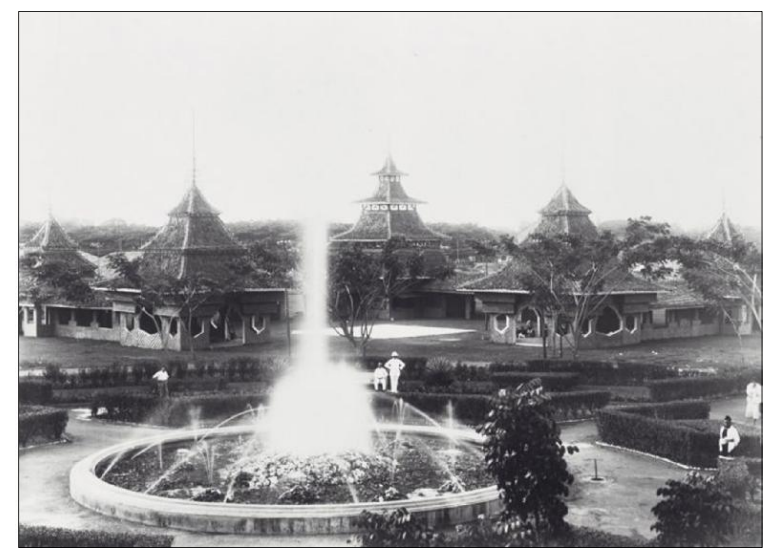

Fig 1. The 1927 Pasar Gambir

The 1927 Pasar Gambir had Joglo-house-style for the roofs. The design was simple in a form of pyramid hip roof and the architectural composition was symmetrical. The pavilions followed three divisions of traditional houses such as lower-middle-upper parts. The lower part of the pavilions consisted of square columns. Although there was no base for the column nor the use of stilts the three division were still present. Other type of pavilions looked lower but the lower part was more elaborated. The roofs of this second type had three tiers with moderate and steeper angles and ended with a long antenna. The body was solid with some openings. The walls created good ventilations as well as fantastic ornaments.
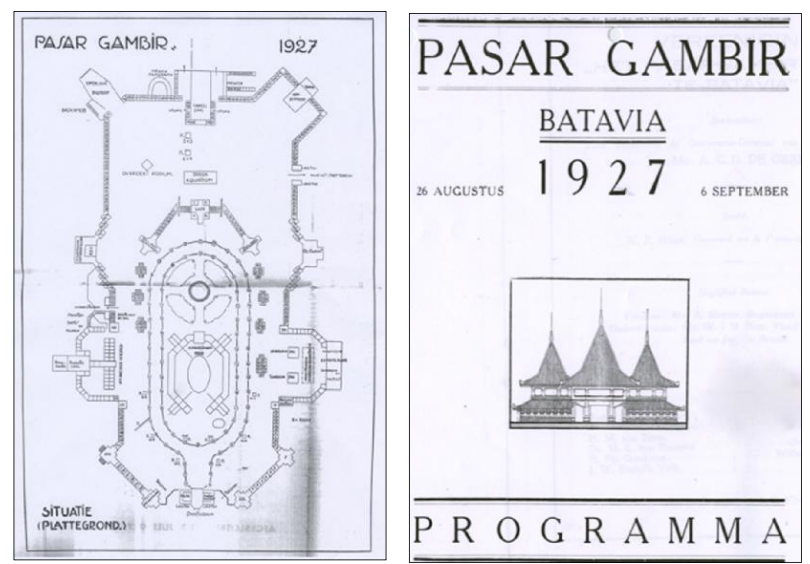

Fig 2. Program and Plan of the 1927 Pasar Gambir. Programma Van Den Pasar Gambir 1927.

The image in the 1927 Pasar Gambir's program showed the symmetrical arrangement of the pavilions. The main entrance was the tallest building, accompanied by twin buildings. The main entrance to the fair consisted of the three identical pavilions with the middle pavilion was placed in front of the other two pavilions to enhance the architectural compositions. At the central area of the fair were the main restaurant and the water fountain complimenting the dance floor located at the central part of the main restaurant.

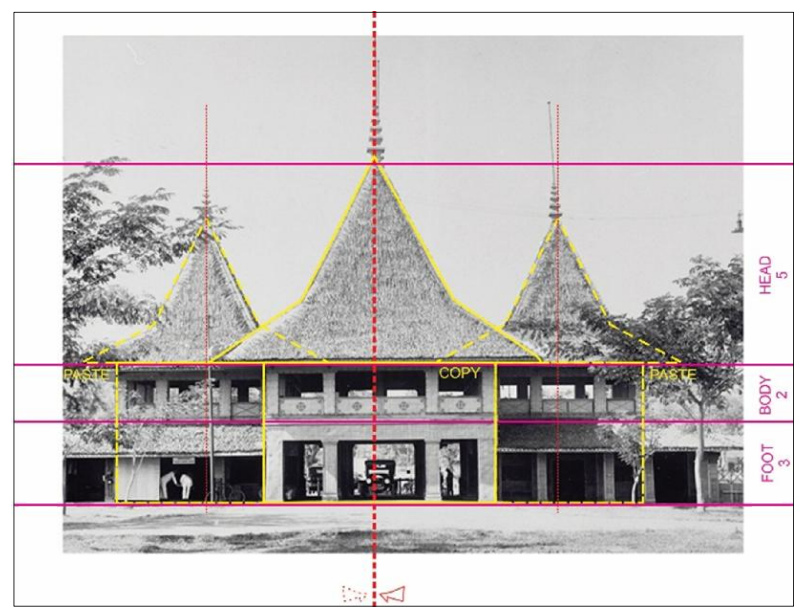

Fig 3. The main pavilion of the 1927 Pasar Gambir.

Although the two pavilions stood on the sides were placed behind the central pavilion, all of the pavilions created a symmetrical architectural language. The open lower parts of the pavilions also created a continuous flow and connection that allowed visitors to move easily. The upper floor of the pavilions had only half walls that created visual connection to the fair inside and created lighter structures. Columns had functions not only as 
entrances but also as visual framing of the fair and let visitors to glance of the fair.

In relation to form, the entrance could be identified as Indies traditional houses with three divisions, such as the head, the body, and the foot. The head was the highreaching roof that combined pyramid hip roof and basic hip roof and also completed with a pinnacle on the top. Then, the body was the second floor of the building that was assumed as the observation deck, and the foot was the first floor which was the main entrance. As the vertical proportion, the four column stepped on the ground and hold the second floor and also the thatch. The vertical line and the horizontal line from the second floor composed the body and foot building proportion. The head was seen as the most dominant part in the building proportion rather than the body and the foot.

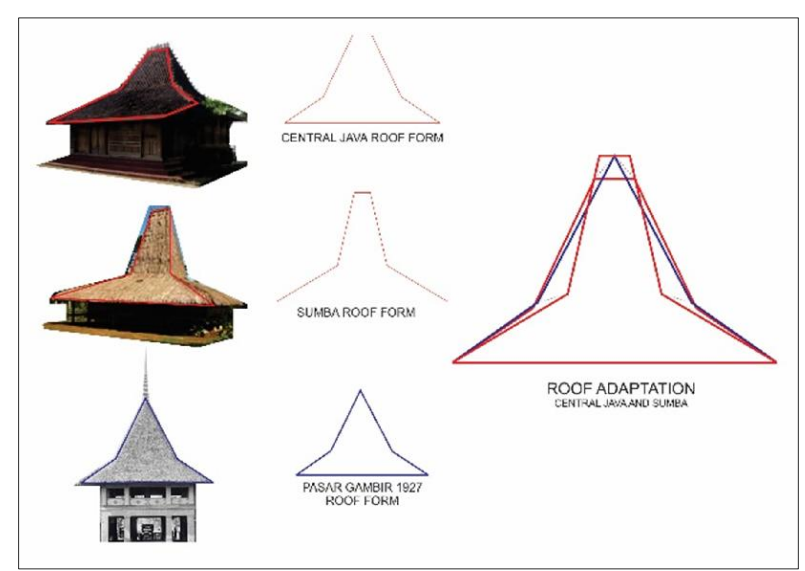

Figure 4. The adaptation of Sumba and Javanese roofs

The expression of the native adoption was dominant in roof design. The roofs can be said combining Sumba and Javanese roof style and proportion, but the roof ridge on the top was changed into a pointed one. Many Indies traditional society believed that the pointed roof was a connection the sky and the upper world that would bring wealthy and good things to the house. Using this Indies familiar roof form might have triggered a feeling of getting good things to the fair.

\subsection{The 1928 Pasar Gambir}

The design of the pavilions of the 1928 Pasar Gambir held from 28 August to 9 September was very interesting. The roof was still a dominant part of the pavilion but proportion of the roof was higher than in previous years. The roof apparently was inspired of Batak Karo architecture of North Sumatra. There were apparently six parts in one big pavilion with the last two upper parts of the pavilion showed Batak Karo roof. Natural materials - timber, bamboo, thatch and fiber were used as well as tenon joints and wooden pegs. The pavilions had typical traditional construction of post, beam and lintel with flexible nail-less joints, and nonload bearing walls. The lowest part of the pavilions was built on stilts, another common characteristic of Indies architecture.
Pavilions in Pasar Gambir were built not only to show local character but also to respond to Indies' hot and wet monsoon climate. With pavilions built on stilts, air and breezes could moderate the hot tropical temperatures. In reality, the elevation also allows the building stands above storm water runoff and keeps people above malaria-carrying mosquitos and reduces the risk of termites. The sharply inclined roof let the heavy tropical rain to quickly go down, and large overhanging eaves kept water out of the house and provide shading.

The pavilions for the 1928 Pasar Gambir showed a very sophisticated design with the architecture of Batak Karo of North Sumatra could be seen mostly from the roofs. The pavilions had stilts as their bases and the upper floor was a typical room with half walls. The roofs in each pavilion consisted of six parts with some variations such as double tiered pitch roofs located directly above the upper floor and modification in angles or the use of antennas to dramatize the ridges of the roofs.
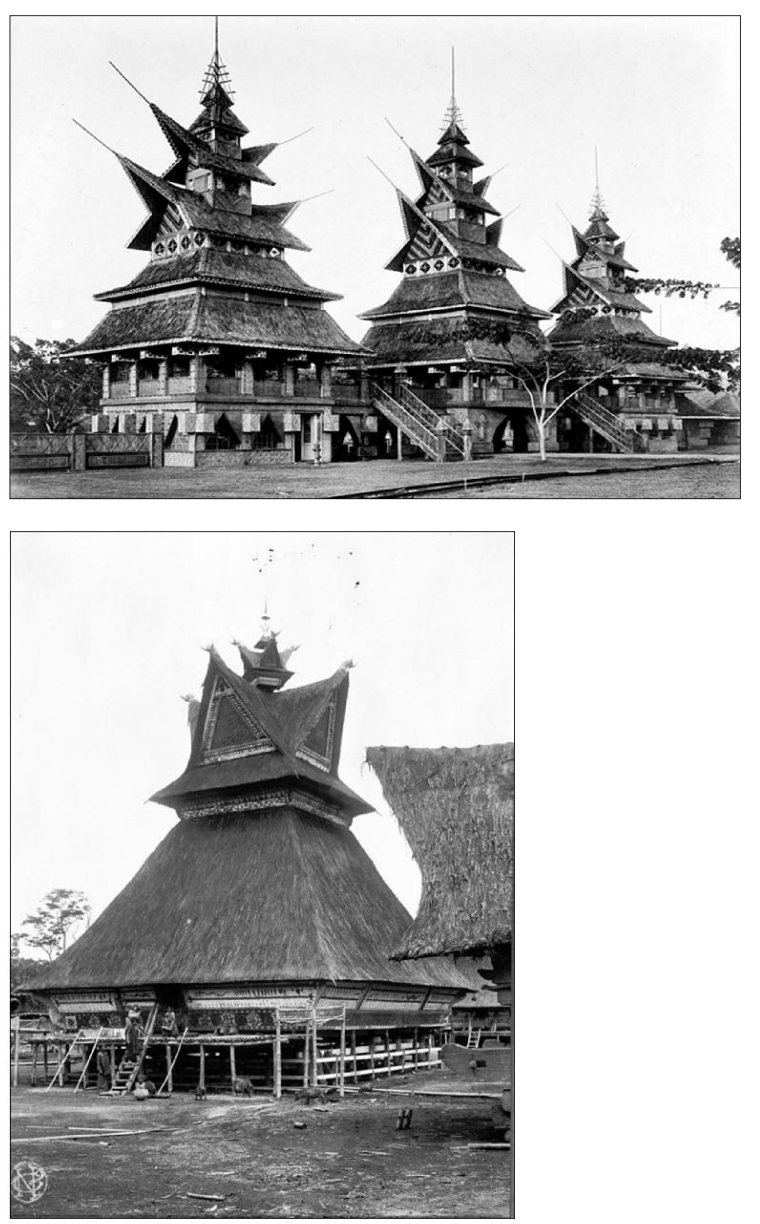

Figure 5. Pavilions of the 1928 Pasar Gambir (Source: National Archive of the Republic of Indonesia) and in comparison with Batak Karo traditional house (1892-1922) (Source: Tropenmuseum TMn_60004175.jpg

The lower part of the pavilion seemed to be strong with the use of square columns. The arches were used in the lower part of the pavilion, which could not be found in Batak Karo architecture and might signify the influence of European architectural forms. Three 
pavilions stood next to each other with porticos and stairs connecting the base and the body of the pavilions.

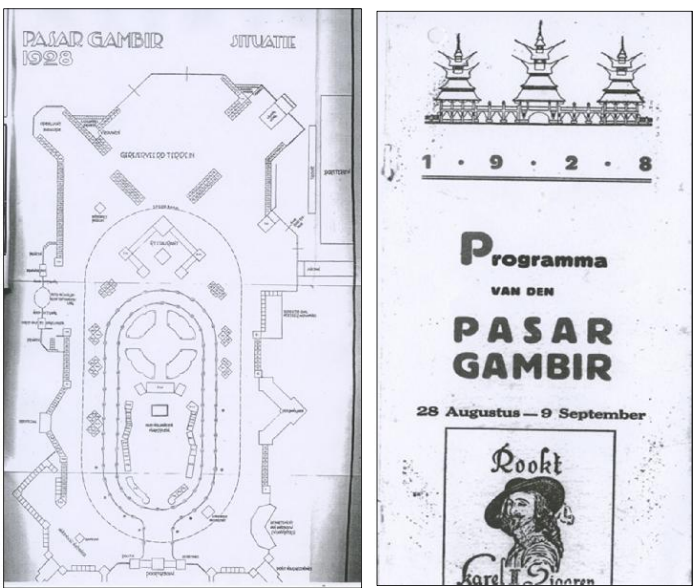

Figure 6. Program and Plan of the 1928 Pasar Gambir. Programma Van Den Pasar Gambir 1928.

Both pavilions of the 1928 Pasar Gambir showed a freedom of quoting and combining some sources. The pavilions designed with festive and experimental atmosphere. Moreover, the lighting was used to accentuate the buildings and attract visitors. There were also some spotlights at the top of the tower to emphasize the entrance to the fair. There was a signage located on the top of the roof that showed the name of the company who did the exhibition.

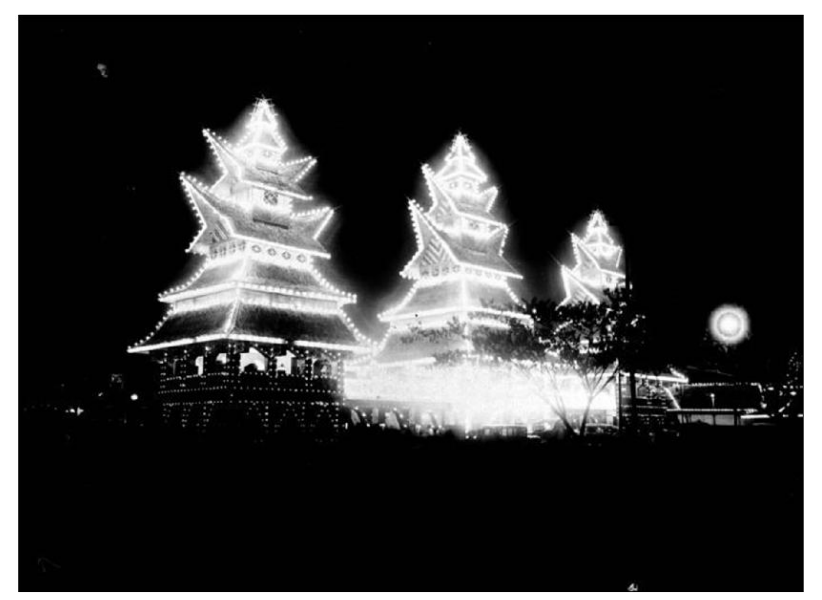

Figure 7. Electric lights for the 1928 Pasar Gambir. Source: Collectie Tropenmuseum De Jaarmarkt 'Pasar Gambir' van 1928 te Jakarta Java bij nacht TMnr 10002593

\subsection{The Main Hall of Institut Teknologi Bandung}

During the colonial era, the Indies were believed to have incorporate European style architecture to their buildings. However, to use European style architecture in a tropical climate was proven to be ineffective. This issue has lead the Indies colonial architects to discuss an approach to create a new style called the Indische Style. According to Martijn Veenendal in Building Modernity Indische Architecture and Colonial Autonomy, 19201940 (2015), the study of the Indische style were prominent among the discussions between Thomas Karsten, Henri Maclaine Pont and Charles Prosper Wolff
Schoemaker. As a modernist architect, Maclaine Pont aimed to incorporate traditional Javanese architecture principles as well as the local construction materials in search of what he believed Indische architecture might be. Maclaine Pont assumed that the presence of traditional architecture might have related to the native's heredity and traditional society beliefs.

One of Maclaine Pont's timeless creation was Aula Utama or the Main Hall of Institut Teknologi Bandung (ITB) that was established in 1920. It was a result of a hybrid design that Maclaine Pont successfully attained upon his attempt to discover Indies style. Maclaine Pont design a mixture of European and native style was embroidered along the concept and construction techniques that assimilate tropical climate in this building. The main hall has portrayed a sense of vernacular architecture that express the richness of Indonesia's traditional values.
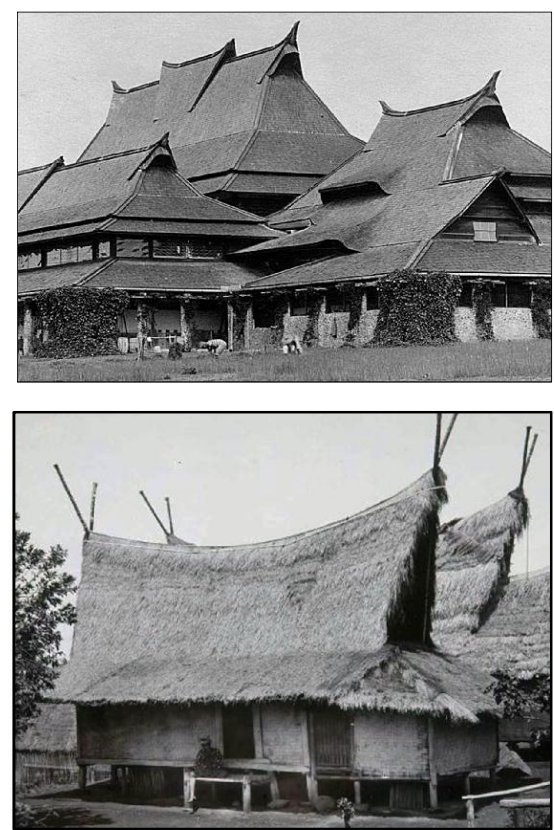

Figure 8. Main Hall of Institut Teknologi Bandung (Source: https://javapost.nl/2012/10/31/tropischmodernisme/architectuur th-bandoeng maclaine-pont $1 /$ ) in comparison with Sundanese traditional house Julang Ngapak. (Source: www.budaya-indonesia.org)

The form of the roof shows similar feature with Sundanese traditional house Julang Ngapak. The construction of the roof is believed to be the combination of lamella and traditional Sundanese roof. At the same time, a glimpse of European architecture is expressed within the wide-span construction of the roof's wooden lamella. The columns were composed of layers of multiplex clamped with steel and at the base of the column was given umpak similar to the pillar composition in Joglo architecture (Hikmayuni R.I., 2012).

Another example of how modernity influences the Main Hall of ITB's design can be seen in the arrangements of round columns in its exterior (Agie W.E., 2014). The use of river stone as its main component made an impression how local materials can also be composed into a modern style but also retain its 
locality. The glass ornaments that decorated the building were also a result of modern influence at the time. However, one of the notable features that can be considered as a response toward tropical climate are the ventilations. The hall was designed in such ways that the air could easily circulate and flow throughout the building. The use of ventilations was also a method to cool down the building as it enables the exchange of air that flows from high temperature to low temperature. Apart from the ventilations, the slanted roof is also a response toward rain as it directs the rainwater to the roof's passageway.

It can be concluded that the Main Hall of ITB campus that Maclaine Pont had designed the building with modern architectural principle and also responding to tropical environment. From Maclaine Pont's approach, we can learn how to deal with the nature and make room for future possibilities that sustain for generations.

\section{Result}

This paper analysed some colonial buildings as a way to discuss the variety of approaches of sustainable architecture by discussing tropical architecture in Indonesia, in relation to the social, cultural and historical conditions during the Dutch colonial era. During the Dutch colonial time in Indonesia there was already ecotechnological practice in architecture with the aim to adapt to local conditions.

Table 1. Eco-Technology approach in 1927-1928 Pasar Gambir Pavilions and The Main Hall of ITB

\begin{tabular}{|c|c|c|c|}
\hline & 1927 Pasar Gambir & 1928 Pasar Gambir & The Main Hall of ITB \\
\hline Roof & $\begin{array}{l}\text { Pyramid hip roof or Joglo- } \\
\text { styled Roof. The inclined roof } \\
\text { is suitable to tropical climate } \\
\text { and provide good shading } \\
\text { during the day. The main roof } \\
\text { consists of three tiers that } \\
\text { allows air to circulate easily } \\
\text { within the building. }\end{array}$ & $\begin{array}{l}\text { Batak Karo-styled roof. The } \\
\text { towering roof creates a space } \\
\text { that directs the air upward to the } \\
\text { pointed roof and exchange the } \\
\text { heat. In return, the low } \\
\text { temperature air will cool off the } \\
\text { building. }\end{array}$ & $\begin{array}{l}\text { Mixed style of Sundanese } \\
\text { traditional house Julang } \\
\text { Ngapak roof with structural } \\
\text { composition similar to Javanese } \\
\text { Joglo-house. } \\
\text { Ceilings were made with } \\
\text { different elevations create } \\
\text { plenty of space for the air to } \\
\text { flow freely within the building }\end{array}$ \\
\hline Building & $\begin{array}{l}\text { The pavilions are built on stilts } \\
\text { so that air may enter the room } \\
\text { from the lower part of the } \\
\text { building. The half walls create } \\
\text { openings and good cross } \\
\text { ventilation in the pavilions. } \\
\text { The wide openings on the lower } \\
\text { floor makes it easier for the air } \\
\text { to circulate around the building } \\
\text { which will reduce the amount } \\
\text { of energy needed to cool the } \\
\text { building. }\end{array}$ & $\begin{array}{l}\text { The pavilions consist of two } \\
\text { tiers and were built on stilts. } \\
\text { Bordered with hall walls, the } \\
\text { pavilion has many openings that } \\
\text { provide the building to have } \\
\text { good cross ventilation. }\end{array}$ & $\begin{array}{l}\text { Slanted roof directs the } \\
\text { rainwater to the rain gutter. A } \\
\text { small gap beneath the upward } \\
\text { roof allows the air to flow } \\
\text { within the building which } \\
\text { makes good ventilations and } \\
\text { cools down the building's } \\
\text { temperature. }\end{array}$ \\
\hline
\end{tabular}




\begin{tabular}{|l|l|l|l|}
\hline Materials & $\begin{array}{l}\text { The use of thatched roof made } \\
\text { the pavilions breathable and } \\
\text { create good ventilations. }\end{array}$ & $\begin{array}{l}\text { Bamboo for walls and columns, } \\
\text { limited use of wood for } \\
\text { columns, and thatch roof. } \\
\text { The use of bamboo and thatch } \\
\text { roof make the pavilions } \\
\text { breathable and create good } \\
\text { ventilations. }\end{array}$ & $\begin{array}{l}\text { Mostly wood and stones for the } \\
\text { columns and walls, including } \\
\text { the use of cement. }\end{array}$ \\
\hline
\end{tabular}

The discussion of pavilions in Pasar Gambir showed some innovation in building forms, although temporary, that pushed the limit of building tradition. The discussion of ITB building also illustrate the possibility of combining western-eastern architectural principles into greater extend and beyond architectural forms. The earlier of eco-technology has shown deeper cultural, historical and local meanings and how traditional architecture is related to the social and cultural dimensions of sustainability.

Authors would like to thank Universitas Indonesia for PITTA Grant or Hibah Publikasi Internasional Terindeks untuk Tugas Akhir Mahasiswa contract No. 2565/UN2.R3.1/HKP.05.00/ 2018 that supports the research conducted for this paper.

\section{References}

1. Guy S. and Moore S.A. Journal of Architectural Education. Sustainable Architecture and Pluralist Imagination. 60(4): 15 - 23 (2007)

2. Lauber, W., Cheret, P., Ferstl, K., \& Ribbeck, E. Tropical architecture: Sustainable and humane building in Africa, Latin America, and South-East Asia. (Munich, Prestel 2005)

3. Lefaivre, L., \& Tzonis, A. Critical regionalism: Architecture and identity in a globalized world. (Munich, Prestel, 2003)

4. Hawkes, D., McDonald, J., Steemers, K. The Selective Environment: Environmental Design and Cultural Identity. (Spon Press, London, 2002)

5. Chang, Jiat-Hwee. "Tropical Variants of Sustainable Architecture: A Postcolonial Perspective." In Handbook of Architectural Theory, edited by Greig Crysler, Stephen Cairns and Hilde Heynen. (London, Sage, 2010)

6. Banham, Reyner. The Architecture of the WellTempered Environment. 2nd ed. pp. 18-28. (London, Architectural Press, 1984)

7. Bay, J.-H., \& Ong, B. L. Tropical sustainable architecture: Social and environmental dimensions. (Oxford, Architectural, 2006)

8. Hikmayuni, R.I. Arsitektur Indis Aula Barat ITB. (2012). Retrieved from: https://www.scribd.com/document/110641741/Arsit ektur-Indis-aula-Barat-Itb

9. Savitri, A. Maclaine Pont: Perintis Arsitektur Indonesia. (2009). Retrieved from wordpress.com: https://anisavitri.wordpress.com/2009/05/19/maclain e-pont-perintis-arsitektur-indonesia/
10. Veenendaal, Martijn. Building Modernity Indische Architecture and Colonial Autonomy, 1920-1940. Bachelor Thesis (2015)

11. Agie, W.E. Mengamati Metode Desain Dari Henri Maclaine Pont Terhadap Gedung Aula Timur Dan Barat ITB. (2014) Retrieved from: https://www.academia.edu/9484882 